\title{
Céline Bricault, La poétique du seuil dans l'œuvre romanesque de Jules Barbey d'Aurevilly
}

\section{Ida Merello}

\section{(2) OpenEdition}

1 Journals

\section{Edizione digitale}

URL: http://journals.openedition.org/studifrancesi/6367

DOI: 10.4000/studifrancesi.6367

ISSN: 2421-5856

\section{Editore}

Rosenberg \& Sellier

\section{Edizione cartacea}

Data di pubblicazione: 1 novembre 2010

Paginazione: 573

ISSN: 0039-2944

\section{Notizia bibliografica digitale}

Ida Merello, "Céline Bricault, La poétique du seuil dans l'œuvre romanesque de Jules Barbey d'Aurevilly», Studi Francesi [Online], 162 (LIV | III) | 2010, online dal 30 novembre 2015, consultato il 11 janvier 2021. URL: http://journals.openedition.org/studifrancesi/6367 ; DOI: https://doi.org/10.4000/studifrancesi. 6367

Questo documento è stato generato automaticamente il 11 janvier 2021.

\section{(c) $(1) \ominus$}

Studi Francesi è distribuita con Licenza Creative Commons Attribuzione - Non commerciale - Non opere derivate 4.0 Internazionale. 


\section{Céline Bricault, La poétique du seuil dans l'œuvre romanesque de Jules Barbey d'Aurevilly}

Ida Merello

\section{NOTIZIA}

CÉLINE BRICAULT, La poétique du seuil dans l'œuvre romanesque de Jules Barbey d'Aurevilly,

Paris, Champion, 2009, pp. 546.

1 Imponente esercizio di metodo, in cui l'opera di Barbey è passata al setaccio per individuare ogni elemento di diaframma, dalle porte alle finestre alle tende alle terrazze ai balconi e perfino agli abiti, per individuare ovunque la stessa funzione di mediazione e di ostacolo e verificarne la funzione simbolica nei diversi ambiti dell'opera. Difficile render conto in maniera discorsiva di un'analisi così tecnica, che non intende certo proporsi come lettura di presentazione sull'autore, bensì come elaborazione di un sistema per un pubblico di specialisti, nell'ambito di un vasto processo di (de)codificazione degli spazi. 